\title{
Vascular tumor and hypertrichosis as skin markers of occult spinal dysraphism
}

\author{
Mohammed Chaouche, Younes Barbach, Abdellah Dah Cherif, Sara Elloudi, \\ Hanane Baybay, Fatima Zahra Mernissi
}

Department of Dermatology and Venereology, University Hospital Hassan II, Fez, Morocco

Corresponding author: Dr. Mohammed Chaouche, MD, E-mail: medch11@hotmail.com

Spina bifida is a congenital disorder with incomplete closure of the spinal column due to a bony vertebral defect. It is a midline defect that occurs during the embryonic period. Depending on the extent of the neural tube defect, various types of spina bifida can be differentiated. Spina bifida occulta, are solely characterized by a bony defect of the vertebral arch, whereas, spina bifida cystica can be distinguished by a protruding cyst, containing either meninges or meninges in combination with spinal cord tissue and are defined as open spinal dysraphisms [1].The cutaneous

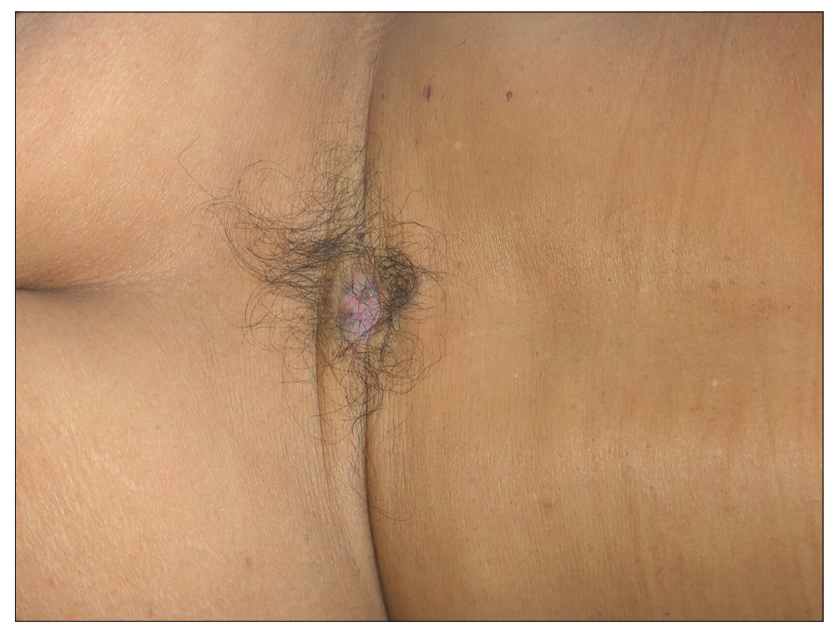

Figure 1: Vascular tumor and hypertrichosis of the lumbar median skin revealing a spina bifida occulta. manifestations accompanying spinal dysraphism that may lead to early recognition of this syndrome and early institution of treatment [2]. A 42-year-old female patient, without history, has developed since birth a nodular vascular firm tumor measuring $25 \mathrm{~mm}$ with hypertrichosis in the median lumbar skin (Fig. 1). The neurological examination did not reveal any deficit, especially concerning lower limbs, the complementary explorations in favor of spina bifida occulta.

\section{Consent}

The examination of the patient was conducted according to the Declaration of Helsinki principles.

\section{REFERENCES}

1. Seromenho-Santos A, Valsassina R, Pimentel J, Miguéns J, Faria CC. Lumbar pseudo-tail associated with dermal sinus - A case report. Neurocirugia (Astur). 2017;28:294-7.

2. Tavafoghi V, Ghandchi A, Hambrick GW, Udverhelyi GB. Cutaneous Signs of Spinal Dysraphism: Report of a Patient With a Tail-like Lipoma and Review of 200 Cases in the Literature. Arch Dermatol. 1978;114:573-7.

Copyright by Mohammed Chaouche, et al. This is an open-access article distributed under the terms of the Creative Commons Attribution License, which permits unrestricted use, distribution, and reproduction in any medium, provided the original author and source are credited.

Source of Support: Nil, Conflict of Interest: None declared.

\footnotetext{
How to cite this article: Chaouche M, Barbach Y, Cherif AD, Elloudi S, Baybay H, Mernissi FZ. Vascular tumor and hypertrichosis as skin markers of occult spinal dysraphism. Our Dermatol Online. 2019;10(e):e10.1.

Submission: 23.01.2019; Acceptance: 25.03.2019

DOI: $10.7241 /$ ourd.2019e.10
} 